\title{
Assessment of Household Food Security in the Face of Climate Change and Variability in the Upper Blue-Nile of Ethiopia
}

\author{
Abayineh Amare and Belay Simane \\ Centre for Environment and Development, College of Development Studies, Addis Ababa University, Addis Ababa 1176, Ethiopia
}

\begin{abstract}
It is widely recognized that climate variability and frequent droughts resulting from El-Nino phenomenon are among the major risk factors affecting agricultural production that might contribute to hunger and food insecurity in East Africa in general and Ethiopia in particular. The objectives of the present study were to examine the food security status and determinants of household food security among 442 randomly selected households in the Muger sub-basin of the Blue-Nile basin using household survey, focus group discussion (FGD) and key informant interview data collection methods. Both descriptive statistics (mean, chi-square test and $t$-test) and binary logit econometric model were used to analyze the data. The results showed that $57.8 \%$ of the households are food secure, while the remaining $42.2 \%$ of the households are food insecure. The binary logit regression results revealed that adoption of soil conservation, small-scale irrigation and employing different agronomic practices are important factors influencing household food security. Moreover, land holding and livestock ownership positively and significantly affected household's food security. The results further showed that family size and distance to the nearest market are important factors affecting food security in the inverse direction. The results highlighted careful investments on sustainable land management practices and small-scale irrigation that reduced sensitivity and increased the adaptive capacity of smallholder farmers to the adverse effect of climate change and variability. This study further highlighted the significance of livestock ownership and landholding in attaining food security under changing climate. The findings call for action based on advocacy family planning to curb population growth and invest in creating functional value-chain that help farmers' viable market for their produces.
\end{abstract}

Key words: Food security, climate change, drought, determinant.

\section{Introduction}

There is an emerging consensus that climate variability and extreme weather events are among the major risk factors affecting agricultural production and food security in Sub-Saharan Africa [1-4]. The effect is particularly pronounced in the rural households of developing countries, such as Ethiopia, where the capacity to cope off the adverse effect is low [2, 5]. The dynamics of climate change also execrate other issues, such as deforestation, land degradation and depletion of water resources that further complicating the challenge of food security [6].

Ethiopia is particularly a vulnerable country due to

Corresponding author: Abayineh Amare, Ph.D., research fields: climate change and food security. in general low adaptive capacity of rural households and exposure to natural and anthropogenic threats [7-9]. The country suffered tremendously from the effect of strongest El-Nino episodes ever recorded in history, which plunged it into limited agricultural production, straining livelihoods and exacerbating food insecurity among poor and vulnerable households [10]. According to the report, the prime effect of El-Nino forced an estimated 10.2 million people to fall under food assistance in 2016 and over one-third of the country's woredas/districts facing food security and nutrition crisis [10].

Food security is a growing concern, particularly under imminent climate change and variability. The World Food Summit of 1996 defined food security as existing "when all people at all times have access to 
sufficient, safe and nutritious food that meets their dietary needs and food preferences for an active and healthy life" [11]. There are three pillars which underpin food security: food availability, food accessibility and food utilization [12]. Previous study confirmed that climate change and variability potentially affected the underpinning pillars at different levels and disrupted the link between them, dwindling their ability to deliver food security [13].

Studies have been undertaken to measure the extent of food insecurity in Ethiopia [14-20]. The studies on food insecurity analyzed the demographic, socio-economic and institutional factors that affect food security, but failed to address the climate factors that are believed to affect food security [2]. This presents an important limitation, since household food security is dictated by a host of environmental factors, in combination with socio-economic and institutional factors. Moreover, a recent study examining determinants of food security indicates the need to be context specific in identifying factors that influence specific investment in food security projects and programs [21]. The knowledge of these environmental factors assists policy to enhance food security through investing on these factors and also has benefits for mainstreaming climate change issues in designing interventions that have a realistic chance of being implemented that are more likely contribute to improving food security outcomes.

Therefore, the objectives of this study were to examine the status of household food security and to analyze a host of climatic, demographic, socio-economic and institutional factors affecting food security of farmers in Muger sub-basin of the Blue-Nile basin in Ethiopia.

\section{Study Area and Methods}

\subsection{Description of the Study Area}

\subsubsection{Bio-physical Setting}

Muger sub-basin is part of the upper Blue-Nile basin and covers a total area of $8,188 \mathrm{~km}^{2}$. Muger River flows from the southeast of the basin into Abbay River. The altitude in Muger sub-basin ranges between 953 masl and 3,550 masl [22]. The highlands in the eastern and southern part of the sub-basin are higher in altitude, greater than 2,600 $\mathrm{m}$ up to $3,550 \mathrm{~m}$. The lowlands along the Muger River have lower altitude less than 1,700 masl [22].

The sub-basin has an annual rainfall varies between $833 \mathrm{~mm}$ and 1,326 $\mathrm{mm}$ [22]. The same source showing lower annual rainfall ranging from $833 \mathrm{~mm}$ up to $1,000 \mathrm{~mm}$ is observed along the river and lowlands. Relatively high rainfall is found in the highlands of the sub-basin. The annual maximum and minimum temperature of the sub-basin varies between $16{ }^{\circ} \mathrm{C}$, $-31.5{ }^{\circ} \mathrm{C}$ and $3-16.5{ }^{\circ} \mathrm{C}$, respectively. Temperature is higher along the river with a maximum of $28-31.5{ }^{\circ} \mathrm{C}$ and minimum of $13-16.5{ }^{\circ} \mathrm{C}$. The sub-basin is characterized by tepid to cool moist highlands. The northwestern part of the lowlands is hot to warm moist lowlands [22].

The major soils of the sub-basin are Leptosols, Luvisols, Vertisols, Fluvisols and Alisols. Leptosols represents the most widely occurring soils within the sub-basin [22]. The second dominant soil is Luvisols. Small patches of Cambisols, Nitosols and Rigosols are also in some parts of the basin.

\subsubsection{Socio-Economic Setting}

According to the current zonal structure, the sub-basin is comprised of three zones: North Shoa, West Shoa, Oromia Regional State Finfine Special Zone. Muger sub-basin covers 15 woredas (districts): Ejersa (Addis Alem), Walmara, Juldu, Mulo, Sululta, Adda Berga, Meta Robi, Yaya Gulelena Debre Libanos, Wichalena Jido, Ginde Beret, Kuyu, Kutaya, Gerar Jarso, Degem and Wara Jarso. The total population of the sub-basin is 2,442,247 [22].

The Muger sub-basin is predominantly rural and the farmers are engaged in small-scale farming and subsistence with mixed agriculture. The main sources of livelihoods in the sub-basin areas/regions are crop 
production and livestock rearing. Map of the study area was presented in Fig. 1.

\subsection{Methodology}

\subsubsection{Sampling Procedure}

The research design was based on multi-stage sampling procedure. In the first stage, the whole sub-basin constituting 15 woredas was grouped into three strata (Kolla, Woyina Dega and Dega agro-ecological zones) based on their agro-ecological characteristics, including the rainfall, soil type and topography. Then, two woredas were randomly selected

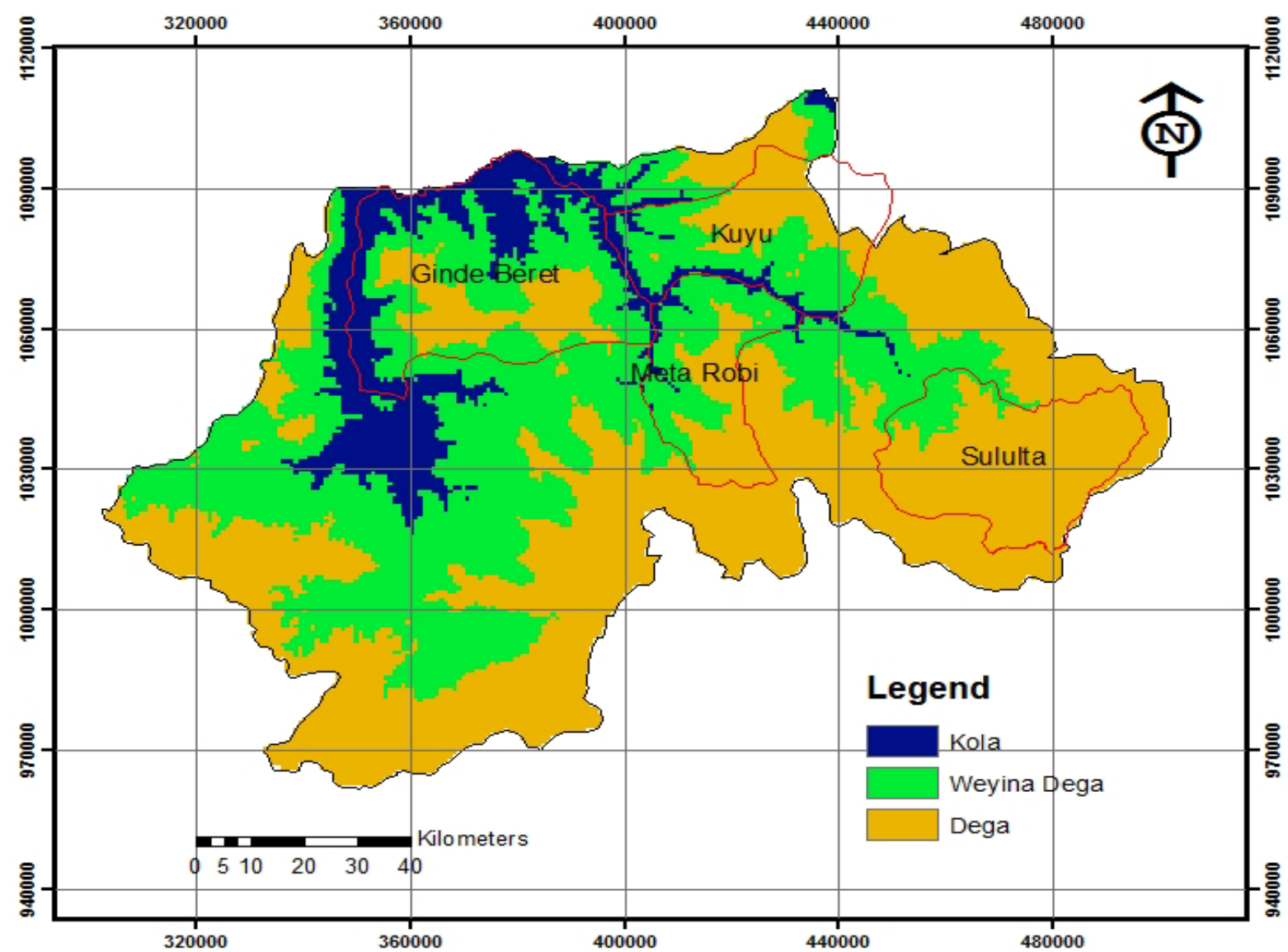

ADMINISTRATIVE MAP OF ETHIOPIA

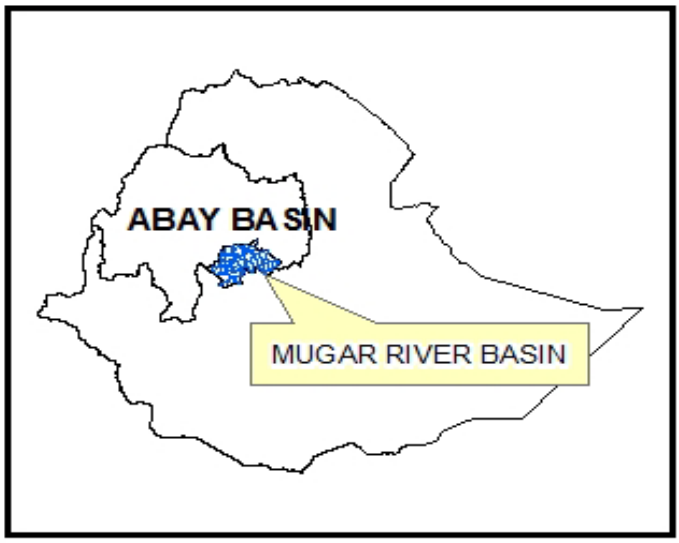

MUGER RIVER BASIN

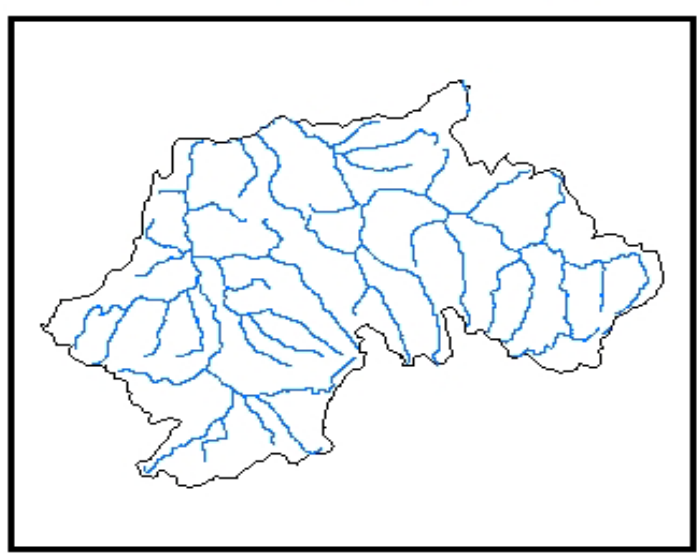

Fig. 1 Agroecology-based classification of Muger sub-basin of the Blue-Nile basin, Ethiopia. 
from Kolla and Dega agro-ecological zones. Similarly, two woredas were also selected from Woyina Dega agro-ecology, using simple random sampling technique. In the second stage, only Peasant Association (PA), the smallest administrative unit found in the sub-basin in each sampled woreda was listed in consultation with agricultural experts in the area. This is mainly to exclude PAs which are not part of the sub-basin in that particular woreda. Then, four PAs were randomly selected from each selected woredas. The third stage was a random selection of 450 respondents from the sampling frame of all the selected PAs, using random sampling technique on the basis of probability proportional to size (PPS). The sampling frame was the list of households, which was obtained from the PAs administration. Households for focus group discussions (FGDs) were also drawn from each identified woreda, and a member of the group was identified with the help of development agents working in the area.

2.2.2 Types of Data and Methods of Data Collection

FGD and household survey were used to collect qualitative and quantitative data, respectively. Data from the FGDs were used to complement the information obtained through a household survey in order to have a better understanding of causes of food insecurity and challenges of food security. There were eight FGDs held in three agro-ecology, of which four were in Woyina Dega and two in each of the other two agro-ecology woredas. The focus groups were composed of 6-8 elders. One focus group in each of agro-ecology was composed of women, who were perceived to have a deep knowledge of food security challenges and impacts of climate change on food security.

Quantitative data were collected through household survey, which comprised of the same sets of questions. The data set consisted of: food security variables (total grain produced, total grain purchased, total grain obtained through Food for Work (FFW), total relief food received, estimated post-harvest loss, total plant products used for seed and total marketed output), adaptation options (Soil and Water Conservation (SWC), small-scale irrigation, agronomic practices and livelihood diversification strategies), asset ownership (landholding and livestock ownership), social capital (membership of local institutions/organizations households), human capital and access to financial capital. The survey also covered data on households' demographic and socio-economic characteristics (age, education, gender and family size), as well as environmental variables, such as access to early warning system, frequency of occurrence of drought and their experience in crop failure due to climate change and variability.

\subsubsection{Data Analysis}

The model selection procedure employed in this study involved in two phases. The first phase was the selection of an appropriate model for classification of households into food security status, and the second one was a selection of an appropriate model to determine factors that affecting food security status in the study area. All quantitative data were analyzed using STATA version 11.

\subsubsection{Household Food Balance Model}

To identify the food secure and insecure households, household food balance sheet was employed. In the calculation of kilocalories intake, the amounts of calorie available to a household were determined through an equation termed as household food balance model (Eq. (1)), which was originally modified by Degefa [23] from the FAO regional food balance model and later used for different studies [24, 25].

Household food balance model is expressed as:

$$
N_{i j}=\left(P_{i j}+B_{i j}+F_{i j}+R_{i j}\right)-\left(H_{i j}+S_{i j}+M_{i j}\right)
$$

where, $N_{i j}$ is net food available for household $i$ in year $j$; $P_{i j}$ is total grain produced by household $i$ in year $j$; $B_{i j}$ is total grain purchased by household $i$ in year $j ; F_{i j}$ is total grain obtained through FFW by household $i$ in 
year $j$; $R_{i j}$ is total relief food received by household $i$ in year $j$; $H_{i j}$ is post-harvest losses to household $i$ in year $j$; $S_{i j}$ is total crop utilized for seed from the home by the household $i$ in year $j$ and $M_{i j}$ is total marketed output by household $i$ in year $j$.

Finally, following Degefa, food security in the present study was measured into the following four steps [23]. First, net food grain available for each household in kilogram $\left(P_{i}\right)$ was converted into equivalent total kilocalories using conversion factors used for Ethiopia [26]. Second, the food supply at the household level calculated in step (i) was used to calculate calories available per person per day for each household. Third, following Federal Democratic Republic of Ethiopia Food Security Strategy, 2,100 kcal calories per person per day were used as a measure of calories required (i.e., demand) to enable an adult to live a healthy and moderately active life. Then, a comparison between the available (supply) and required (i.e., demand) grain food was made. Using 2,100 kcal calories as cut off point, a household whose daily per capita calories available (supply) is less than his/her demand was considered as food insecure, while a household who did not experience a calorie deficit during the year under study was regarded as food secure.

In order to analyze the determinants of food security, both descriptive and econometric analyses were used. Descriptive statistics, such as chi-square test and $t$-test were used for dummy and continuous variables, respectively. Binary logit econometric model was used to analyze the determinants of household food security.

\subsubsection{Binary Logit Model}

It is commonly argued that logit and probit models are usually used to establish the relationship between household characteristics and dichotomous response variable (food security and food insecurity). The advantages of these models over the linear probability model are that the probabilities are bound between zero and one. Moreover, they best fit the non-linear relationships between the response and the explanatory variables. The models specify a functional relationship between the probabilities of being food secure to various explanatory variables.

In principle, one can substitute the probit model for logistic model, as their formulations are quite comparable; the main difference is that the logistic model has slightly flatter tails than the cumulative normal distribution, i.e., the probit curve approaches the axes more quickly than the logistic curve [27]. Therefore, the choice between the two is one of (mathematical) convenience and availability of computer programs. On this score, the logit model is generally used in preference to probit. It is also noted that the logistic distribution has got an advantage over the others in the analysis of dichotomous outcome variables, because it is extremely flexible and easily used model from the mathematical point of view and results in meaningful interpretations [28]. Hence, the logistic model is selected for this study, although both logit and probit models may give a similar result.

The Gujarati logit model is expressed as follows by Eq. (2) [27]:

$$
P_{i}=\mathrm{E}\left(Y=1 / X_{i}\right)=\frac{1}{1+e^{-\left(\beta_{0}+\beta_{1} X_{i}\right)}}
$$

For ease of exposition, Eq. (2) can be expressed as:

$$
P_{i}=\frac{1}{1+e^{-Z_{i}}}
$$

where, $Z_{i}=\beta_{o}+\beta_{1} X_{i}$. If $P_{i}$ is the probability of being food secure, then the probability of being food insecure is given by $1-P_{i}$, which is expressed as follows by Eq. (4):

$$
1-P_{i}=\frac{1}{1+e^{Z_{i}}}
$$

Therefore, this can be written as Eq. (5):

$$
\frac{P_{i}}{1-P_{i}}=\frac{1+e^{Z_{i}}}{1+e^{-Z_{i}}}=e^{Z_{i}}
$$

where, $P_{i} /\left(1-P_{i}\right)$ is simply the odds ratio in favor of food security; the ratio of the probability that the household will be food secure to the probability that it 
will be food insecure.

Taking the natural log of Eq. (5) above, it is possible to arrive at a log of odds ratio, which is linear not only in $X$, but also in the parameters.

$$
L_{i}=\operatorname{Ln}\left(\frac{P_{i}}{1-P_{i}}\right)=Z_{i}=\beta_{o}+\beta_{i} X_{i}
$$

where, $P_{i}$ is the probability of being food secure ranging from zero to one; $Z_{i}$ is a function of $n$-explanatory variables $\left(X_{i}\right)$ and is expressed as Eq. (7): $Z_{i}=\beta_{0}+\beta_{1} X_{1}+\beta_{2} X_{2}+\beta_{3} X_{3}+\beta_{4} X_{4}+\ldots \ldots+\beta_{n} X_{n}$ where, $\beta_{0}$ is the intercept or constant term; $\beta_{1}, \beta_{2}, \beta_{3}$, $\beta_{4}, \ldots \ldots \beta_{n}$ are the slope of the equation in the model (parameters to be estimated); $L_{i}$ is log of odds ratio; $X_{i}$ is a vector of relevant household characteristic.

If the disturbance term $\left(U_{i}\right)$ is introduced, the logit model becomes:

$$
\begin{gathered}
Z_{i}=\beta_{0}+\beta_{1} X_{1}+\beta_{2} X_{2}+\beta_{3} X_{3}+ \\
\beta_{4} X_{4}+\ldots \ldots+\beta_{n} X_{n}+U_{i}
\end{gathered}
$$

Finally, the parameters of the model are estimated using the maximum likelihood (ML) method [27-29]. It is noted that the ML method is a general method of estimation that is applicable to a large variety of problems [29]. ML methods suggest choosing or estimating the value of the parameter that maximizes the logarithm of the likelihood function itself and the same result is obtained. Method of ML yields value for the unknown parameters, which maximizes the probability of obtaining the observed set of data, and such a method is preferred when data at micro or individual level are acquired [28]. However, there is a recognition that the OLS techniques can be used when the data set is sufficiently large and are grouped into the interval.

\subsection{Definition of Variables and Working Hypotheses}

After the analytical procedures are clearly delineated, it is necessary to identify the potential explanatory variables that can influence household food security. Consequently, review of the literature on economic theory, past research findings, experts and author's knowledge of the food security situation of the study area are used to identify the potential determinants of household food security in the study area. The dependent variable in this study is food security, which is a dichotomous variable taking the value 1 if the household is food-secure and 0 , otherwise. To dichotomize the household, the resulting average kilocalories consumed per adult equivalent (AE) per day is compared with the adequacy norm (the minimum subsistence kilocalories requirement) set by the Federal Democratic Republic of Ethiopia (FDRE) as 2,100 kcal for the country [30]. Based on critical review of the literature, the following explanatory variables are hypothesized to have an influence on household food security:

(1) Distance from market center: This variable is a continuous variable measured in hours; it will take from the home of the household to the nearest market place. Closeness to market centers creates access to additional income via off-farm/non-farm employment opportunities, easy access to information on inputs and transportation [31, 32]. It is has been noted that the farther the market center is, the lesser the income from the sale of farm produce. Especially for perishable commodities, if the market place is located far away from the farm, the commodity may perish before reaching the market. And to avoid such incidences, the farmer sells his output for cheaper price thus reducing the income and bringing negative impact on household food security. Therefore, it is hypothesized that there is a negative association between distance to the nearest market center and household food security.

(2) Age of the household head: It is a continuous variable measured in a number of years. Previous study indicated that age has a significant effect on household food security [33]. That is, the older the household head, the more experience he has in farming and weather forecasting, and become more risk averter. As a result, the chance for such household to be food secure is high. Therefore, it is hypothesized 
that age of household head has a positive impact on household food security.

(3) Household family size: It refers to the total number of household members who lived and ate with household head for at least six months and is expressed in AE. In subsistence economy coupled with limited agricultural inputs, having large family size will demand more food than the labor they contribute to production [31, 34, 35]. Therefore, it is expected that household size and food security are negatively related.

(4) Gender of household head: It is a dummy variable which takes 1 if the household head is male, 0 otherwise. Female-headed households have less access to improved technologies, credit, land and extension services compared to men [36]. In contrast, male-headed households are in a better position to pull labor force than the female-headed ones. Women farmers may need a long adjustment period to diversify their income sources fully and become food secure [37]. Empirical evidence drawn from Ethiopia found that male-headed households are more food secure than female headed households [38]. Therefore, it is hypothesized that female-headed households are less likely to be food secure compared to male headed households.

(5) The level of education of the household head: It is a continuous variable defined as the level of grades or schooling years attained by the household heads. A large body of literature noted that household heads with better educational background are believed to have a chance to diversify household's income sources, adopt better production technologies, accept technical advice from the extension workers and can better manage their farm as compared to the illiterate ones [17, 33, 39]. Educated households have a better chance of managing their farm by adopting improved practices, which in turn increases total yield. It is assumed that a literate household head often tends to adopt new skills and ideas, which in turn have positive effects on food security [17, 33, 39]. It is expected that the educational status of the household head and household food security have a positive association.

(6) The size of cultivated land: Size of cultivated land has positive impact on household food security [40, 41]. This variable represents the total cultivated land size which is owned, rented in, contracted in and obtained through the gift of a household measured in a hectare. Households with larger farm size are more likely to be food secure compared to those with smaller farm size [17, 38, 39]. A large size of cultivated land implies more production and availability of food grains and the possibility that the household gets more output is high as it remains the basic capital input in food production. It is hypothesized that farmers who have larger cultivated land are more likely to be food secure than those with a smaller area.

(7) Livestock holding: It is a continuous variable and measured in tropical livestock unit (TLU). Households that own livestock can produce milk, milk products and meat for direct consumption [42]. Moreover, livestock contributes to the provision of draft power and manure which increase agricultural productivity. Farmers sell their livestock and livestock products and purchase food grains during seasonal food shortages. Increased livestock holding leads to decrease household vulnerability to food insecurity, especially in times of drought when crops fail to yield that in turn improved food security status $[17,38,39$, 43]. Thus, livestock owned is hypothesized to have a positive relation with food security.

(8) Access to credit service: It is a dummy variable taking the value 1 if the household takes credit, 0 otherwise. Credit provides the opportunity to use inputs and this promotes production. Households that have an easy access to credit service have the possibility to invest in different farming and some other income-generating activities and improve their production. As a result, household's income and food consumption pattern will improve [17, 34, 42]. Therefore, it is rational to expect a positive association between access to credit service and food security. 
(9) Advisory services: It refers to the average number of visit made by the extension agents to a household per month. Farm households that use advisory services by development agents are more likely to adopt new technologies and advance in their production. It is expected that extension service widens the household's knowledge with regard to the use of improved variety and agricultural technologies and has positive impact on household food security. Therefore, it is hypothesized that the frequency of contact with extension agents positively influences food security.

(10) Off-farm/non-farm income: It is a dummy variable which takes a value of 1 if the household participated in off-farm and/or non-farm activities, and 0 if the household did not participate in any of the two activities. Most farmers commonly generate their income from their farm. However, they occasionally look for the external source of off-farm incomes and non-farm activities to purchase clothes, inputs, food and food-related items [44]. Many literatures noted that the ability to get access to off-farm/non-farm activities determines the success of households and their members in managing food insecurity which could serve as livelihood diversification strategies [12, 31, 39]. On the other hand, off-farm activities can take labor away from agriculture and may decrease conservation investments and these are threats to food security. Participation in off-farm/non-farm income sources is expected positively and negatively associated with food security.

(11) Small-scale irrigation: It refers to a dummy variable taking a value of 1 if the household used small-scale irrigation and 0 , otherwise. Small-scale irrigation in the Ethiopian context refers to smallholder farms with the size of scheme amounting less than 200 ha [45]. Empirical study has shown that access to reliable irrigation water can enable farmers to adopt new technologies and intensify cultivation, leading to increased productivity, overall higher production and greater returns from farming [46]. Similarly, another empirical result found that in moisture-stressed areas, getting moisture through irrigation would improve the situation and help to boost agricultural outputs [39]. Evidence suggested that small-scale irrigation has benefited some households by providing an opportunity to increase agricultural production through double cropping and by taking advantage of modern technologies and high yielding crops that called for intensive farming [47]. Accordingly, it is hypothesized that participating in small-scale irrigation would have a positive influence on food security of the household.

(12) Soil conservation measures: A soil conservation measure is a dummy variable, taking value 1 if a household is practicing soil conservation activities and 0 if the household did not apply or practice any soil conservation measures. In Ethiopia, erosion and soil degradation are constraints to food production since unsustainable management of soils, upon which agriculture depends, considerably affects food security [48]. Practicing any soil conservation techniques will mitigate land degradation problem through maintaining soil fertility, which increases crop production, ceteris paribus. Thus, a household which practices any type of soil conservation measures is more likely to be food secure.

(13) Occurrence of drought (climate): It refers to a continuous variable with the number of times that drought occurred in the study area during the past 25 years. The experience shows that marked yield fluctuations and food insecurity are associated with climatic variability. The country has been known by the reoccurring drought that resulted in food shortage. Food security in the country has been negatively affected by drought. Experiences revealed that drought has a significant influence on national annual per capita food supply [49]. It is, therefore, hypothesized that a number of times drought occurred in the area is negatively related to food security.

(14) Drought-tolerant seeds: It is a dummy variable that takes a value of one if farmers used improved seeds and zero, otherwise. Improved seeds may 
withstand drought and erratic rainfall distribution when it is resistant to moisture stress. It augments agricultural productivity by boosting overall production, which in turn contributes to attaining households' food security at the household level [32, 50]. Hence, a household which uses improved seeds is expected to be more food secure than the non-users.

(15) Access to early warning information: It is a dummy variable taking 1 if the household receives early warning information and 0 , otherwise. It is argued that farmers in drought-prone areas are responsive to changes in climatic conditions through what is commonly called "response farming". To reduce the production risk of total crop failure, they change their cropping patterns based on the climatic conditions they anticipate and observe [51]. Similarly, findings from different areas reveal that better access to weather information helped farmers to use drought-tolerant crop varieties, invest in soil conservation measures, use irrigation and diversify livelihood options in response to climate change problem [52-54]. Moreover, people-centered early warning information systems empower communities to prepare for and confront the impacts of climate extreme events [55]. The effect of access to weather information on household food security is expected to be positive.

(16) Social capital: Membership to social groups was used as a proxy for social capital. It is a continuous variable measured in a number of social groups in which the household is a membership. Local institutions functioning at the community level and social capital play a role in maintaining food security at the individual and household levels [56]. Similarly, evidence sought that social capital has a positive impact on achieving food security [57]. It is hypothesized that social capital has a positive association to household food security.

\section{Results and Discussion}

\subsection{Status of Food Security}

Fig. 2 presented the food security status of farm households that had been determined using descriptive analysis. The result of the household food balance model revealed that from the total sample households, $57.8 \%$ households were found to be food secure who fulfill the minimum recommended daily calorie (2,100 kcal/AE/day as mentioned in Ref. [30]). While $42.2 \%$ of them failed to supply this daily minimum requirement.

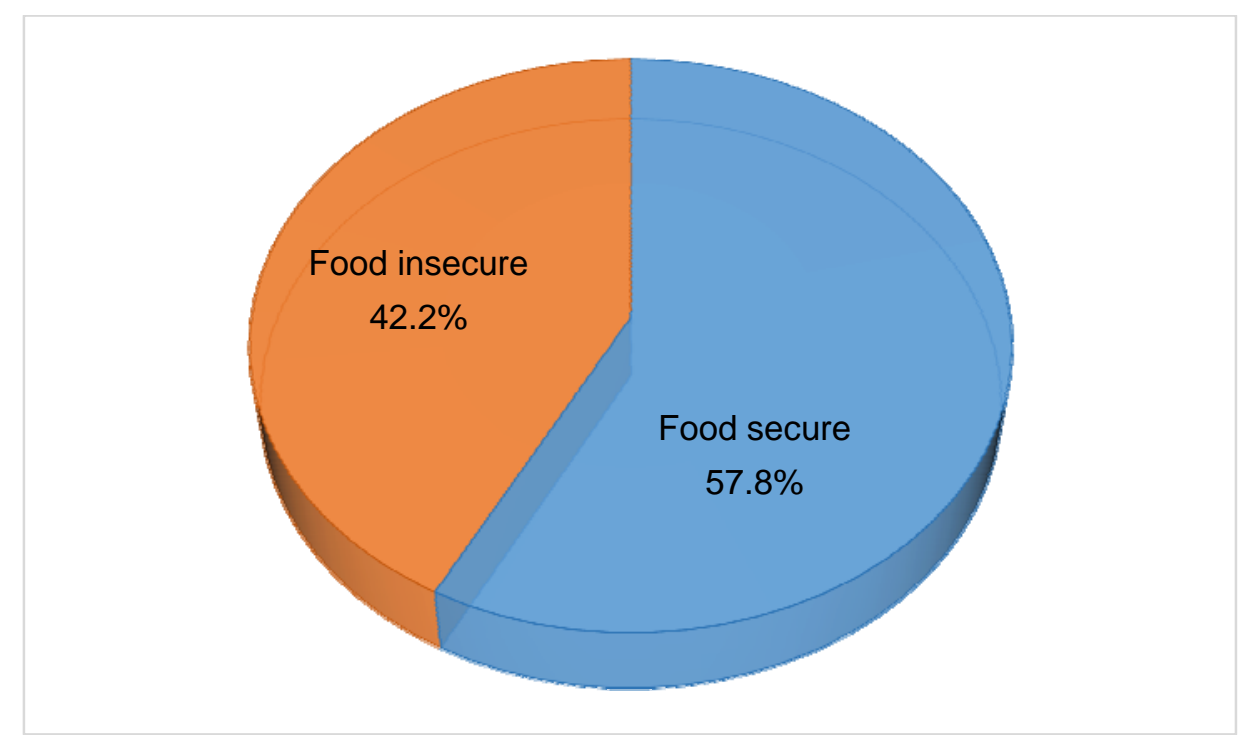

Fig. 2 Percentage of food secure and food insecure sampled households in the study area. 
Tables 1 and 2 present the descriptive statistics for dummy and continuous variables that are helpful to observe differences between food secure and insecure households. The chi-square analysis shows that greater proportion of food secured households used soil and water conservation, small-scale irrigation, drought-tolerant seeds and different livelihood options. The result further indicates that large proportions of food secure households are male-headed households, accessible to extension advisory services, credit and early warning information as compared to their counterparts. The independent $t$-test result shows that there is a significant mean difference between food secure and insecure households with respect to social groups, landholding, distance to the main market and livestock ownership.

\subsection{Econometric Analysis}

A binary logit model was used to identify potential explanatory variables affecting household's food security. Before running the analysis, variables assumed to have an influence on food security were

Table 1 Association between possible determinants (discrete variables) and household food security.

\begin{tabular}{|c|c|c|c|c|c|}
\hline Variable & Categories & Food secure $(n)$ & Food insecure $(n)$ & Chi-square value & Significance \\
\hline \multirow{3}{*}{ Agro-ecology } & Kolla & 54 & 86 & \multirow{3}{*}{$35.722^{* * *}$} & \multirow{3}{*}{0.000} \\
\hline & Woyina Dega & 137 & 55 & & \\
\hline & Dega & 57 & 40 & & \\
\hline \multirow{2}{*}{ Soil conservation } & No & 154 & 149 & \multirow{2}{*}{$20.630^{* * *}$} & \multirow{2}{*}{0.000} \\
\hline & Yes & 94 & 32 & & \\
\hline \multirow{2}{*}{ Small scale irrigation } & No & 158 & 154 & \multirow{2}{*}{$24.098^{* * *}$} & \multirow{2}{*}{0.000} \\
\hline & Yes & 90 & 27 & & \\
\hline \multirow{2}{*}{ Drought-tolerant seeds } & No & 221 & 157 & \multirow{2}{*}{$0.562^{\mathrm{NS}}$} & \multirow{2}{*}{$0.453^{\mathrm{NS}}$} \\
\hline & Yes & 27 & 24 & & \\
\hline \multirow{2}{*}{ Off-farm/non-farm income } & No & 230 & 143 & \multirow{2}{*}{$17.396^{* * *}$} & \multirow{2}{*}{0.000} \\
\hline & Yes & 18 & 38 & & \\
\hline \multirow{2}{*}{ Gender of the $\mathrm{HH}$} & Female & 21 & 44 & \multirow{2}{*}{$20.426^{* * *}$} & \multirow{2}{*}{0.000} \\
\hline & Male & 227 & 137 & & \\
\hline \multirow{2}{*}{ Advisory service } & No & 67 & 102 & \multirow{2}{*}{$37.720^{* * *}$} & \multirow{2}{*}{0.000} \\
\hline & Yes & 181 & 79 & & \\
\hline \multirow{2}{*}{ Access to credit } & No & 182 & 118 & \multirow{2}{*}{$3.341^{*}$} & \multirow{2}{*}{0.068} \\
\hline & Yes & 66 & 63 & & \\
\hline \multirow{2}{*}{ Early warning } & No & 89 & 111 & \multirow{2}{*}{$27.209^{* * *}$} & \multirow{2}{*}{0.000} \\
\hline & Yes & 159 & 70 & & \\
\hline
\end{tabular}

*, ${ }^{* * *}$ Significant at $10 \%$ and $1 \%$, respectively; NS: not significant; HH: household head.

Table 2 Association between possible determinants (continuous variables) and household food security

\begin{tabular}{|c|c|c|c|c|c|c|}
\hline \multirow{2}{*}{ Variable } & \multicolumn{2}{|c|}{ Food secure } & \multicolumn{2}{|c|}{ Food insecure } & \multirow{2}{*}{$t$-value } & \multirow{2}{*}{ Significance } \\
\hline & Mean & SD & Mean & SD & & \\
\hline Age of the $\mathrm{HH}$ & 45.75 & 12.257 & 45.70 & 12.878 & 0.039 & 0.969 \\
\hline Education status of $\mathrm{HH}$ & 2.57 & 3.553 & 2.44 & 3.223 & $0.401^{\mathrm{NS}}$ & 0.688 \\
\hline Family size & 5.77 & 1.902 & 6.09 & 2.137 & -1.650 & 0.100 \\
\hline Social capital & 2.84 & 1.262 & 2.36 & 1.345 & $3.743^{* * *}$ & 0.000 \\
\hline Landholding & 3.04 & 1.605 & 1.76 & 1.415 & $8.758^{* * *}$ & 0.000 \\
\hline Distance to the market & 1.55 & 0.795 & 1.79 & 0.993 & $-2.645^{* * *}$ & 0.009 \\
\hline Livestock in TLU & 7.98 & 4.805 & 4.61 & 4.472 & $7.455^{* * *}$ & 0.000 \\
\hline Climate & 4.33 & 3.06 & 4.21 & 3.353 & $0.382^{\mathrm{NS}}$ & 0.703 \\
\hline
\end{tabular}

*** Significant at 1\%; NS: not significant; SD: standard deviation; HH: household head; TLU: tropical livestock unit. 
tested for multicollinearity and degree of association among variables using variance inflation factors and contingency coefficient, respectively. The test results show that there is no multicollinearity and association problem among the variables. Among 17 variables fitted into the model, agro-ecology, soil and water conservation, small-scale irrigation, drought-tolerant seeds, family size, land ownership, distance to the market and livestock ownership are found to be significant in determining food security of the household. The influence of all the significant variables is in the expected direction. Table 3 below provided the parameter estimates of the binary logit model results:

(1) Agro-ecology: The effect of agro-ecology can also be seen as significant where, on average, households in Woyina Dega agro-ecology are more food secure compared to those in Kola agro-ecology. On the other hand, households living in Dega agro-ecology do not show significant differences on food security compared to those in Kola agro-ecology. The odds ratio in favor of food security reveals that a shift from Kola agro-ecology to Woyina Dega agro-ecology increases the probability of the household being food secure by 2.5016 . This may be explained by the fact that as one moves from Kola to Woyina Dega agro-ecology in the study area, the rainfall and vegetation cover increases which result in high crop production by the household and hence enhances food security. This implies that households in areas with Kola agro-ecology need to be paid special attention compared to those in Woyina Dega agro-ecology.

(2) Soil conservation: The model results in Table 3 showed that adoption of conservation measures were found to have a significant influence on food security at less than $1 \%$ significance level. This shows, in terms of food security, there exists a statistical difference between households who practiced soil and water conservation measures and those who did not. On the basis of the results, one might conclude that investment on soil and water conservation measures generate substantial benefit in reduction of land degradation that has a substantial impact on agricultural productivity and that in turn has positive benefits on food security. The FGDs held in the study area reveal that using soil bunds, stone bunds, check dams and hillside terracing seem to yield better results in terms of contributing to household food security. On the same vein, in the model analysis, it has been noted that households using these conservation measures have larger kilocalories per AE per day. The present study is consistent with studies conducted in another part of the country $[34,58]$.

(3) Small-scale irrigation: It had a positive and significant relationship with food security at $1 \%$ level, implying that households who have practiced small-scale irrigation on their farm are more likely to be food secure than those did not practice. The odds ratio in favor of food security increases by the factor 5.3356. Based on the results of this study, three possible explanations may be presented. First, it provides an opportunity to grow a crop during non-rain season that provides multiple harvests per year possible. This is mainly because irrigation allows farmer flexibility in length or number of growing seasons [47, 59]; second, it helps to avoid crop failure due to drought problem in areas where rainfall does not provide sufficient moisture like moisture-stressed areas of the rural areas of Muger sub-basin; third, it also helps to adopt new technologies [46]. For example, it is observed that farmers who practiced small-scale irrigation in the study area adopted drip irrigation technology and drought-tolerant maize variety. This means households who used small-scale irrigation produce more food for household consumption and for sale and have better chance to be food secure than those who did not practice irrigation on their farmland. A similar relation was observed in Refs. [17, 39, 60]. It is, therefore, imperative to devise viable small-scale irrigation projects that critically consider the availability of suitable land, water 
resources, labor, non-irrigation production inputs, access to the market and appropriate water-lifting technologies.

(4) Drought-tolerant seeds: Use of drought-tolerant seeds is another variable, which was found to have a positive and significant impact on household food security $(P<0.05)$. For example, farmers in the study area switched to drought-tolerant maize varieties from local maize varieties. The odds ratio for this variable in favor of food security is 3.5195. This indicates that the probability of households to be food secure increases by 3.5195, if a household has access to and use drought-tolerant seed. This can be explained by the fact that in moisture-stressed area, due to climate change and variability, like the study area, using drought-tolerant seed would reduce crop failure that in turn enhance crop production.

(5) Family size: Family size is found to be negatively and significantly $(P<0.05)$ impacted to determine household food security in the study area (Table 3), implying that the probability of food security decreases with an increase in household size. The odds ratio in favor of the probability of being food secure decreases with an increase in the family size. More specifically, the odds ratio in favor of food security, ceteris paribus, decreases by a factor of 0.8345 as the family size increases by one member. The probable reason is that increasing household size within households whose agricultural land is less productive results in increased demand for food. This implies larger household sizes require increased food expenditure and competition for limited resources. This creates a mismatch between the food demand and with the existing food supply from own production and this ultimately end up with the household becoming food insecure. This result is consistent with

Table 3 Parameter estimates of determinants of household food security.

\begin{tabular}{|c|c|c|c|}
\hline Variables & Odds ratio & $Z$-value & $P$-value \\
\hline \multicolumn{4}{|l|}{ Agro-ecology (Kolla) } \\
\hline Woyina Dega & 2.5016 & $2.26^{* *}$ & 0.024 \\
\hline Dega & 0.5385 & $-1.11^{\mathrm{NS}}$ & 0.266 \\
\hline Soil conservation & 12.0575 & $4.28^{* * *}$ & 0.000 \\
\hline Small-scale irrigation & 5.3356 & $2.92^{* * *}$ & 0.003 \\
\hline Drought-tolerant seeds & 3.5195 & $2.26^{* *}$ & 0.024 \\
\hline Gender of the $\mathrm{HH}$ & 0.7132 & $-0.75^{\mathrm{NS}}$ & 0.452 \\
\hline Age of the $\mathrm{HH}$ & 0.9991 & -0.94 & 0.348 \\
\hline Education & 0.9955 & $-0.11^{\mathrm{NS}}$ & 0.912 \\
\hline Family size & 0.8345 & $-2.54^{* *}$ & 0.011 \\
\hline Social capital & 1.1708 & $1.27^{\mathrm{NS}}$ & 0.205 \\
\hline Size of landholding & 1.3466 & $2.50^{* *}$ & 0.013 \\
\hline Advisory service & 1.5349 & $1.43^{\mathrm{NS}}$ & 0.153 \\
\hline Access to credit & 1.0637 & $0.20^{\mathrm{NS}}$ & 0.839 \\
\hline Distance to market & 0.6178 & $-3.01^{* * *}$ & 0.003 \\
\hline Early warning & 1.4817 & $1.45^{\mathrm{NS}}$ & 0.147 \\
\hline Livestock in TLU & 1.1061 & $2.71^{* * *}$ & 0.007 \\
\hline Climate & 1.0078 & $0.17^{\mathrm{NS}}$ & 0.867 \\
\hline Constant & 0.4447 & $-0.99^{\mathrm{NS}}$ & 0.324 \\
\hline Pseudo $R^{2}$ & 0.3130 & & \\
\hline Log-likelihood function & -200.67955 & & \\
\hline $\operatorname{LR} \operatorname{chi}^{2}(18)$ & 182.85 & & \\
\hline Prob $>$ chi $^{2}$ & 0.0000 & & \\
\hline Number of observations & 429 & & \\
\hline
\end{tabular}

**, ${ }^{* * *}$ Significant at 5\% and 1\%, respectively; NS: not significant; HH: household head. 
a large number of empirical findings conducted in many different parts of Ethiopia and elsewhere in the world [17, 31, 34, 35, 61].

(6) Size of landholding: In agreement with a prior assumption, the size of landholding has a significant and positive influence on household food security. This means that households with large landholding produce more food for household consumption and for sale and have better chance to be food secure than those having relatively small size of land with the concept that the increase in agricultural output has been attained through the expansion of cultivated land [62]. The result reveals that the odds ratio in favor of food security increases by the factor 1.3466 when the area under cultivation is increased by 1 ha. This outcome is in line with the finding in Refs. [17, 34, 63].

(7) Distance to the market: Distance to the major market is found significantly and negatively related to food security in the study area. The odds ratio in favor of food security decreases by a factor of 0.6178 when the distance to the main market increased by one walking hour. The consensus on households nearer to market centers had better chances to be food secure than those who are away from market centers is due to the reason that households nearer to the market center have the probability of selling their produce and purchase food from the market. The results from the FGDs held in the study area show that households sold their livestock and livestock product to purchase food for family consumption during drought and crop failure problem. Holding other explanatory variables constant, the odds ratio in favor of food security decreases by a factor of 0.6178 when the distance in hours of walk increases by $1 \mathrm{~h}$. Also, other findings confirm the result of this study [31, 64].

(8) Livestock ownership: As it can be evidenced from many studies concerning household food security, livestock possession affects food security as it is the backbone of the farm economy, especially in mixed farming systems. The result showed that total livestock owned by the household is found to be significant at less than $1 \%$ and positively related to food security in the study area. The odds ratio in favor of food security increases by a factor of 1.1061 when the amount of livestock owned by a household rises by one TLU. The possible explanations are: besides it creates employment opportunity for the member of the family, it provides milk and milk products, and meat for direct consumption and for the market; it contribute draft power and manure for crop production; during famine and food shortage the farm households would be able to sell their own livestock and purchase food grains. This is in line with other empirical evidence in Ethiopia [17, 39].

\section{Conclusions and Policy Implications}

The main objectives of the present study were to examine the food security status and the determinants of household food security under changing climate among selected farm households. The household food balance model shows that $42.2 \%$ of the selected households failed to meet the minimum daily calorie intake per adult per day. The overall results reveal that adoption of adaptation options found to significantly and positively influence household food security. It is, therefore, imperative to devise viable projects on soil conservation, irrigation and agronomic practices that consider the availability of suitable land, water resources, labor, production inputs, access to the market and capital resources.

The result further found that size of landholding was positively and significantly associated with household food security. This result suggests promoting and supporting smallholders to make optimal land allocation decision and to use improved soil and nutrient management that will have potential impact on improving soil quality that in turn improve agricultural productivity in the study area. Moreover, the potential influnce of livestock ownership on household food security suggests strong consideration of programs which improve the diversity and productivity of livestock assets, such as improved feed, 
better animal health, market infrastructure and improved variety that can adapt the emerging climate change and variability. It is also noted that family size and distance to the market are important factors negatively influencing household food security. To this end, promotion of labour-intensive technologies and the creation of labour-intensive rural employment opportunities would be the policy agenda to increase food security situation of the study area.

\section{Acknowledgments}

Profound gratitude were pressed to Addis Ababa University; the German Academic Exchange Service (DAAD), Germany; African Climate Change Fellowship Program; International Development Research Centre (IDRC) for their financial support in accomplishing this paper.

\section{References}

[1] Thornton, P., and Herrero, M. 2014. "Climate Change Adaptation in Mixed Crop-Livestock Systems in Developing Countries.” Glob. Food Secur. 3 (2): 99-107.

[2] Demeke, A., Keil, A., and Zeller, M. 2011. "Using Panel Data to Estimate the Effect of Rainfall Shocks on Smallholders Food Security and Vulnerability in Rural Ethiopia.” Climatic Change 108 (1-2): 185-206.

[3] Temesgen, T., Hassan, R., Ringler, C., Alemu, T., and Yesuf, M. 2009. “Determinants of Farmers' Choice of Adaptation Methods to Climate Change in the Nile Basin of Ethiopia.” Glob. Environ. Chang. 19 (2): 248-55.

[4] Kidane, G., Abebe, T., and Degefie, T. 2006. Estimating Crop Water Use and Simulating Yield Reduction for Maize and Sorghum in Adama and Miesso Districts Using the Cropwat Model. Report Number 31, Pretoria.

[5] Falco, S., Veronesi, M., and Yesuf, M. 2011. "Does a Daptation to Climate Change Provide Food Security? A Micro-perspective from Ethiopia.” Am. J. Econ. 93 (3): 829-46.

[6] Delgado, J. A., Groffman, P. M., Nearing, M. A., Goddard, T., Reicosky, D., Lal, R., Kitchen, N. R., Rice, C. W., Towery, D., and Salon, P. 2011. "Conservation Practices to Mitigate and Adapt to Climate Change." $J$. Soil Water Conserv. 66 (4): 118-29.

[7] Parry, M., Canziani, O., Palutikov, J., Van der Linden, P., and Hanson, C., eds. 2007. "Contribution of Working Group II to the Fourth Assessment Report of the Intergovernmental Panel on Climate Change.” In Climate
Change 2007: Impacts, Adaptation and Vulnerability. Cambridge and New York: Cambridge University Press.

[8] World Bank. 2010. "Economics of Adaptation to Climate Change, Ethiopia.” World Bank. Accessed October 20, 2016. https://openknowledge.worldbank.org/handle/109 86/12504.

[9] Schipper, E. L. F., and Conway, D. 2011. “Adaptation to Climate Change in Africa: Challenges and Opportunities Identified from Ethiopia.” Glob. Env. Chang. 21 (1): 227-37.

[10] FAO. 2017. Regional Overview of Food Security and Nutrition in Africa 2016. The Challenges of Building Resilience to Shocks and Stresses. Accra, 39.

[11] FAO, 1996. "Socio-Political and Economic Environment for Food Security.” Presented at the World Food Summit, 1996.

[12] Barrett, C. B. 2005. "Measuring Food Insecurity." Science 327 (5967): 825-8.

[13] Gregory, J. P., Ingram, S. J., and Brklacich, M. 2005. "Climate Change and Food Security.” Phil. Tranzaction R. Soc. 360: 2139-48.

[14] Gebre-Selassie, S. 2004. Food Insecurity and Poverty in Ethiopia: Evidence and Lessons from Wollo. EEA/EEPRI Working Paper, Report Number 3/2004, Addis Ababa, Ethiopia.

[15] Berhanu, A. 2004. "The Food Security Role of Agriculture in Ethiopia.” Electron. J. Agric. Dev. Econ. 1 (1): 138-53.

[16] Freihiwot, F. 2007. Food Security and Its Determinants in Rural Households in Amhara Region. Addis Ababa, Ethiopia: Ethiopian Development Research Institute (EDRI).

[17] Bogale, A., and Shimelis, A. 2009. "Household Level Determinants of Food Insecurity in Rural Areas of Dire Dawa, Eastern Ethiopia.” African J. Food, Agric. Nutr. Dev. 9 (9): 1914-26.

[18] Hadleya, C., Linzerb, D. A., Tefera, B., Abebe, G., Fasil, T., and Lindstrome, D. 2011. "Household Capacities, Vulnerabilities and Food Insecurity: Shifts in Food Insecurity in Urban and Rural Ethiopia during the 2008 Food Crisis.” Soc. Sci. Med. 73 (10): 1534-42.

[19] Zegeye, T., and Hussien, H. 2011. "Farm Households' Food Insecurity, Determinants and Coping Strategies: The Case of Fadis District, Eastern Oromia, Ethiopia.” Ethiop. J. Agric. Econ. 8 (1): 1-35.

[20] Shimeles, A., Janekarnkij, P., and Wangwacharakul, V. 2011. "Dimensions of Food Insecurity and Adoption of Soil Conservation Technology in Rural Areas of Gursum District, Eastern Ethiopia.” Kasetsart J. (Soc. Sci.) 32 (1): 308-18.

[21] Beyene, F. 2014. "Determinants of Food Security under Changing Land-Use Systems among Pastoral and 


\section{Assessment of Household Food Security in the Face of Climate Change and Variability in the Upper Blue-Nile of Ethiopia}

Agro-pastoral Households in Eastern Ethiopia.” Env. Dev. Sustain. 17 (5): 1163-82.

[22] Denekew, A., and Bekele, S. 2009. Characterization and Atlas of the Blue Nile Basin and Its Sub Basins. Addis Ababa: International Water Management Institute.

[23] Degefa, T. 1996. "Belg Crop Production as a Strategy of Households' Food Security: A Comparative Study of Belg Grower and Non-belg Grower Farmers in Munessa Wereda, Arsi Zone.” M.A. thesis, Addis Ababa University.

[24] Eshetu, B. 2000. "The Underlying Causes of Household Food Security and Coping Strategies: The Case of Legambo Wereda, South Wollo Zone, Amhara Region, North Eastern Ethiopia.” M.Sc. thesis, Addis Abeba University, Ethiopia.

[25] Mesay, M. 2010. "Food Security Attainment Role of Urban Agriculture: A Case Study from Adama City.” EJBE 1 (1): 68-106.

[26] Agren, G., and Gibson, R. 1968. Food Composition Table for Use in Ethiopia. Stockholm: Swedish International Development Authority, and Addis Ababa, Ethiopia: Ethiopian Nutrition Institute.

[27] Gujirati, D. N. 1995. Basic Econometrics, 3rd ed.. New York: McGraw-Hill Co.

[28] Hosmer, D. W., and Lemeshow, S. 1989. Applied Logistic Regression. New York: A Wiley. Interscience Publication.

[29] Maddala, G. S. 1981. Introduction to Econometrics: Business Economics, 2nd ed.. New York: Florida University.

[30] Federal Democratic Republic of Ethiopia Food Security Strategy (FDRE). 2002. "Food Security Strategy.” Addis Ababa, Ethiopia. Accessed Jaunary 2015. http://www.africanchildinfo.net/clr/policy\%20per\%20cou ntry/ethiopia/ethiopia_foodsecurity_1996_en.pdf.

[31] Gemechu, F., Zemedu, L., and Yusuf, J. 2016. "Determinants of Farm Household Food Security in Hawi Gudina District, West Hararghe Zone, Oromia Regional National State, Ethiopia.” J. Agric. Ext. Rural Dev. 8 (2): 12-8.

[32] Dorward, A., Poole, N., Morrison, J., Kydd, J., and Urey, I. 2003. "Markets, Institutions and Technology: Missing Links in Livelihood Analysis.” Dev. Policy Rev. 21 (3): 319-32.

[33] Abebaw, S. 2003. "Dimensions and Determinants of Food Security among Rural Households in Dire Dawa, Eastern Ethiopia.” M.Sc. thesis, Alemaya University.

[34] Beyene, F., and Muche, M. 2010. "Determinants of Food Security among Rural Households of Central Ethiopia: An Empirical Analysis.” Q. J. Int. Agric. 49 (4): 299-318.

[35] Zemedu, L., and Mesfin, W. 2014. "Smallholders' Vulnerability to Food Insecurity and Coping Strategies:
In the Face of Climate Change, East Hararghe, Ethiopia." J. Econ. Sustain. Dev. 5 (24): 86-101.

[36] Green, W. H. 2000. Econometric Analysis, 4th ed.. New Jersy: Prentice-hall, Inc.

[37] Christina, H., Thomson, M., Jennifer, S., and Anderson, S. 2001. "Addressing Food Security in Africa via Multiple Livelihood Strategies of Women Farmers.” J. Food Policy 26 (1): 177-207.

[38] Belayneh, L. 2005. “Analysis of Food Insecurity Causes: The Case of Rural Mete Woreda, Eastern Ethiopia.” M.Sc. thesis, Haramaya University.

[39] Tirfe, Z., and Hamda, H. 2011. "Farm Households' Food Insecurity, Determinants and Coping Strategies: The Case of Fedis District, Easter Oromia, Ethiopia.” Ethiop. J. Agric. Econ. 8 (1): 1-35.

[40] Mulugeta, T. 2002. "Determinants of Household Food Security in Eastern Oromia, Ethiopia: The Case of Boke District of Western Hararghe Zone.” M.Sc. thesis, Alemaya University.

[41] Ayalew, Y. 2003. "Identification and Intensity of Food Insecurity and Coping Strategies of Rural Households in North Shoa: The Case of Lalomama.” M.Sc. thesis, Alemaya University.

[42] Kifle, L., and Yosef, G. 1999. "The Food Security Situation in Ethiopia: Concept, Status and Trends.” In Proceedings of the First National Workshop of NOVIB Partners Forum on Sustainable Land Use, edited by Assefa, T. Addis Ababa, Ethiopia, 32-47.

[43] Little, P. D., Stone, M. R., Mogues, T., Catro, A. P., and Negatu, W. 2006. "Moving in Place: Drought and Poverty Dynamics in South Wollo, Ethiopia." J. Dev. Stud. 42 (2): 200-25.

[44] Markos, E. 1997. Demographic Response to Ecological Degradation and Food Insecurity, Drought Prone Areas in Northern Ethiopia. Amsterdam, The Netherlands: PDOD Publications.

[45] Mengistie, D., and Kidane, D. 2016. "Assessment of the Impact of Small-Scale Irrigation on Household Livelihood Improvement at Gubalafto District, North Wollo, Ethiopia.” Agriculture 6 (3): 1-22.

[46] Hussain, I., Namara, R. E., and Madar, S. 2004. Water for Food Security for the Poor. Colombo, Sri Lanka: Asian Development Bank, 85-6.

[47] Woldeab, T. 2003. "Irrigation Practices, State Intervention and Farmers Life-Worlds in Drought-Prone Tigray, Ethiopia.” Ph.D. thesis, Wageningen University, the Netherlands.

[48] Von Braun, J., Rosegrant, M. W., Pandya-Lorch, R., Cohen, M. J., Cline, S. A., Brown, M. A., and Bos, M. S. 2005. "New Risks and Opportunities for Food Security: Scenario Analysis for 2015 and 2050.” International Food Policy Research Institute. https://ageconsearch.umn. 
edu/bitstream/42269/2/2020dp39.pdf.

[49] World Bank. 2010. The Social Dimension of Adaptation to Climate Change in Ethiopia. Development and Climate Change Discussion Paper, Number 14. Wahington, D.C.: World Bank.

[50] Lipton, M. 2005. The Family Farm in a Globalizing World: The Role of Crop Science in Alleviating Poverty. Report Number 41. Washington, D.C.: Intl. Food Policy Res. Inst.

[51] Alemu, D., Hassana, M., and Teferra, M. 2008. "Determinants of Household Food Security." East African J. Sci. 2 (1): 68-78.

[52] Nhemachena, C., and Hassan, R. 2007. Micro-level Analysis of Farmers' Adaptation to Climate Change in Southern Africa. IFPRI Discussion Paper 00714. Washington, D.C.: International Food Policy Research Institute (IFPRI) and Centre for Environmental Economics and Policy in Africa (CEEPA).

[53] Maddison, D. 2007. "The Perception of and Adaptation to Climate Change in Africa.” Policy Research Working Paper, Number WPS 4308. Washington, D.C.: World Bank.

[54] Deresse, T., Yehualashet, H., and Rajan, D. S. 2014. "Climate Change Adaptations of Smallholder Farmers in South Eastern Ethiopia.” J. Agric. Ext. Rural Dev. 6 (11): 354-66.

[55] Hassan, R., and Nhemachena, C. 2008. "Determinants of African Farmers' Strategies for Adapting to Climate Change: Multinomial Choice Analysis.” African J. Agric. Resour. Econ. 2 (1): 83-104.

[56] Tolosa, D. 2009. "An Assessment of the Role of Local Institutions and Social Capital in Household Food Security: A Case Study at Two Rural Communities in Oromiya Zone, Amhara Region.” In Proceedings of the 16th International Conference of Ethiopian Studies, edited by Ege, S., Aspen, H., Teferra, B., and Bekele, S. Trondheim: Norwegian University of Science and Technology.

[57] Dzanja, J., Christie, M., Fazey, I., and Hyde, T. 2015. “The Role of Social Capital in Rural Household Food Security: The Case Study of Dowa and Lilongwe Districts in Central Malawi.” J. Agric. Sci. 7 (12): 165-76.

[58] Holden, S., and Shiferaw, B. 2004. "Land Degradation, Drought and Food Security in a Lessfavored Area in the Ethiopian Highlands: A Bio-economic Model with Market Imperfections.” Agric. Econ. 30 (1): 31-49.

[59] Burke, M., and Lobell, D. 2010. "Food Security and Adaptation to Climate Change: What Do We Know?” In Climate Change and Food Security, edited by Lobell, D., and Burke, M. London, New York: Springer, 133-53.

[60] Makombe, G., Mekonnen, D. K., and Aredo, D. 2007. “A Comparative Analysis of Rained and Irrigated Agricultural Production in Ethiopia.” Irrig. Drain. Syst. 21 (1): 35-44.

[61] Obayelu, A. E. 2012. "Households' Food Security Status and Its Determinants in the North-Central Nigeria.” Food Econ. 9 (4): 241-56.

[62] Haile, H. K., Alemu, Z. G., and Kudhlande, G. 2005. "Causes of Household Food Insecurity in Koredegaga Peasant Association, Oromiya Zone, Ethiopia.” Agric. Econ. Res. Policy Pract. South Africa 44 (4): 543-60.

[63] Aidoo, R., Mensah, J. O., and Tuffour, T. 2013. "Sekyere-Afram Plains District of Ghana." In Proceedings of the 1st Annual International Interdisciplinary Conference, Kumasi, 24-6.

[64] Feleke, S. T., Kilmer, R. L., and Gladwin, C. H. 2005. "Determinants of Food Security in Southern Ethiopia at the Household Level.” Agric. Econ. 33 (3): 351-63. 